\title{
PENGARUH STRATEGI PEMBELAJARAN REACT TERHADAP PRESTASI BELAJAR FISIKA SISWA DITINJAU DARI KETERAMPILAN PROSES SAINS SISWA KELAS X SMA NEGERI 7 MALANG
}

\author{
Nisfil Maghfiroh Meita \\ Universitas Wiraraja Sumenep \\ Email: Nisfilmeita35@gmail.com
}

\begin{abstract}
ABSTRAK
Pembelajaran konvensional perlu dialihkan ke pembelajaran dengan pendekatan konstruktivis untuk meningkatkan prestasi belajar siswa. Tujuan dari penelitian ini adalah untuk mengetahui pengaruh strategi REACT dan pembelajaran konvensional terhadap prestasi belajar fisika. Penelitian dilaksanakan di SMAN 7 Malang dan diterapkan pada siswa kelas X yang terdiri atas 2 kelas eksperimen dan kontrol. Desain penelitian adalah penelitian kuasi-eksperimen dengan rancangan faktorial 2x2. Sampel yang digunakan pada penelitian melibatkan 33,3\% siswa berketerampilan proses sains tinggi dan 33,3\% siswa berketerampilan proses sains rendah. Jumlah sampel yang digunakan 104 siswa. Keterampilan proses sains dinilai dengan menggunakan lembar observasi. Prestasi belajar fisika diperoleh dari nilai tes 20 soal pilihan ganda. Ranah kognitif yang digunakan adalah C1 s/d C4 taksonomi Bloom. Analisis data untuk uji hipotesis adalah uji ANAVA 2 jalur dan uji Tukey. Hasil penelitian menunjukkan bahwa prestasi belajar fisika siswa yang belajar dengan strategi REACT lebih tinggi daripada prestasi belajar fisika siswa yang belajar secara konvensional. Terdapat interaksi antara strategi pembelajaran dan keterampilan proses terhadap prestasi belajar fisika. Prestasi belajar fisika siswa yang mempunyai keterampilan proses sains tinggi belajar dengan strategi REACT lebih tinggi daripada prestasi belajar fisika siswa yang mempunyai keterampilan proses sains tinggi yang belajar secara konvensional. Prestasi belajar fisika siswa yang mempunyai keterampilan proses sains rendah yang belajar secara konvensional lebih tinggi daripada prestasi belajar fisika siswa yang mempunyai keterampilan proses sains rendah yang belajar dengan strategi REACT.
\end{abstract}

Kata Kunci: Strategi REACT, prestasi belajar fisika, keterampilan proses sains

\section{PENDAHULUAN}

Pembelajaran dengan pendekatan konstruktivis diharapkan mengganti pembelajaran fisika konvensional yang salah satu cirinya berpusat pada guru (teacher centered). Pembelajaran dengan pendekatan konstruktivis yang diterapkan dalam penelitian ini adalah strategi REACT. Strategi REACT merupakan strategi penerapan pembelajaran kontekstual (Crawford, 2001:3-15), dan pembelajaran kontekstual atau Contekstual Teaching and Learning (CTL) berkembang dari faham konstruktivis (Nugroho, 2010:113). Tujuan dari pergantian pembelajaran konvensional menuju pembelajaran dengan pendekatan konstruktivis adalah untuk menerapkan pembelajaran yang aktif. Piramida pembelajaran menjelaskan bahwa pembelajaran yang aktif cenderung membuat siswa lebih ingat materi pembelajaran (Salman, 2009:26). Strategi REACT telah diterapkan oleh Margono (2007), Fauziah (2010), Hidayat (2010), Marthen (2010), dan Yuniawatika (2011) yang menemukan dampak positif dari strategi REACT.

Sintaks dari trategi REACT yaitu: 1) relating (menghubungkan) yaitu siswa dibimbing untuk menghubungkan materi yang sedang dipelajarinya dengan 
konteks pengalaman kehidupan nyata atau pengetahuan yang sebelumnya; 2) experiencing (mengalami) yaitu siswa dibimbing untuk melakukan percobaan sehingga siswa mengalami sendiri konsep yang dipelajari; 3) apllying (menerapkan) yaitu memberikan latihan soal juga menjelaskan materi pembelajaran, sehingga siswa dapat mengetahui kesalahan dan kebenaran dari pembelajaran yang dilakukan; 4) cooperating (kerjasama) yaitu pembelajaran dengan mengkondisikan siswa agar bekerja sama, merespon dan berkomunikasi antar siswa; dan 5) transferring (mentransfer) yaitu pemberian tugas yang terkait erat dengan materi pelajaran (CORD, 2003). Strategi pembelajaran REACT dipilih karena merupakan penerapan pembelajaran konstruktivis yang dikolaborasikan dengan pembelajaran kooperatif. Pembelajaran yang menerapkan pendekatan konstruktivis maka siswa dapat mengkonstruk pengetahuan yang dimilikinya. Penerapan pembelajaran kooperatif dapat mengatasi jumlah alat yang terbatas dan mengkondisikan siswa untuk belajar secara berkelompok. Perbedaan strategi REACT dengan strategi pembelajaran konstruktivis lainnya terlihat pada sintaksnya khususnya pada tahap cooperating, pada tahapan ini ditunjukkan dengan jelas bahwa siswa harus melakukan diskusi sedangkan pada strategi pembelajaran konstruktivis lainnya tidak memfokuskan pada pembelajaran kooperatif. Pada strategi REACT siswa dapat menghubungkan materi pelajaran dengan fenomena kehidupan sehari-hari, melakukan pengamatan, memanfaatkan hasil penelitian, dan menggunakan pengetahuan untuk mengatasi permasalahan baru, serta melatih bekerjasama. Strategi REACT dapat memberikan pengalaman belajar secara nyata, melibatkan siswa secara aktif dalam pembelajaran, meningkatkan pemahaman siswa melalui pengamatan dan mengembangkan kemampuan keterampilan proses sains siswa.

Proses pembelajaran fisika tidak cukup dilaksanakan dengan menyampaikan informasi tentang konsep dan prinsip-prinsip. Tias (2008) menyatakan bahwa guru sains disarankan untuk menekankan pembelajaran pada konsepkonsep dan keterampilan proses sains dibandingkan hanya sekedar menghafal fakta atau informasi. Proses pembelajaran fisika selain mengembangkan penilaian prestasi belajar siswa, sebaiknya guru juga mengembangkan penilaian keterampilan proses sains siswa. Prestasi belajar adalah hasil yang telah diperoleh siswa dari pengalaman-pengalaman dan latihan-latihan yang diikutinya selama pembelajaran (Dimyati, 2006:55).

Prestasi belajar merupakan hal yang penting dalam pembelajaran. Prestasi belajar adalah hasil yang telah diperoleh siswa dari pengalamanpengalaman dan latihan-latihan yang diikutinya selama pembelajaran (Dimyati, 2006:55). Winkel (1996:272) menjelaskan bahwa prestasi belajar merupakan suatu kegiatan yang berupaya untuk mengetahui tingkat keberhasilan yang telah diterapkan. Untuk mengukur pencapaian tujuan maka perlu menggunakan evalusi prestasi belajar. Surachmad menjelaskan bahwa evaluasi prestasi belajar merupakan usaha mengukur pencapaian tujuan kegiatan belajar yang mencerminkan perubahan tingkah laku, kecakapan dan status pelajar dalam menelaah materi belajar pada jangka waktu tertentu (Sakdiyah, 2009:36). Berdasarkan uraian di atas dapat disimpulkan bahwa prestasi belajar merupakan tingkat pencapaian siswa yang tercermin dari perubahan tingkah laku yang terjadi dalam diri siswa dan dapat diukur dengan tes prestasi belajar. Prestasi belajar merupakan penilaian hasil belajar siswa yang difokuskan pada prestasi belajar fisika yaitu tes kemampuan kognitif siswa setelah seluruh materi pembelajaran kalor 
selesai. Ranah kognitif yang digunakan pada tes prestasi belajar fisika berdasarkan dimensi proses kognitif Bloom yang mencakup ranah kognitif $\mathrm{C} 1$ (mengingat), $\mathrm{C} 2$ (memahami), $\mathrm{C} 3$ (menerapkan), dan $\mathrm{C} 4$ (menganalisis).

Mengembangkan penilaian prestasi belajar siswa penting akan tetapi mengembangkan penilaian keterampilan proses sains siswa juga penting. Keterampilan proses sains tidak dapat berdiri sendiri, keterampilan proses sains perlu didukung dengan kemampuan kognitif, afektif dan psikomotor. Temiz (2006) memaparkan, keterampilan proses sains membutuhkan latar belakang pengetahuan minimum dalam sains supaya siswa dapat merespon pertanyaan dengan tepat selain itu, siswa menggunakan pikiran logis dan kemampuan meneliti. Selain itu, Yunus dan Hashim (2007) menyatakan bahwa keterampilan proses sains akan meningkatkan kemampuan berpikir kritis, prestasi dan sikap siswa dalam belajar. Oleh sebab itu, pengembangan keterampilan proses sains dapat mempengaruhi tingkat pemahaman siswa pada materi tertentu. Keterampilan proses sains menurut Rezba (2006:4-6) terdiri atas keterampilan proses sains dasar (basic science process skills) dan keterampilan proses sains terintegrasi (integrated science process skills). Keseluruhan komponen indikator keterampilan proses terdiri dari 18 item. Keseluruhan indikator keterampilan proses sains dapat dilihat pada Tabel 1.

Tabel 1. Komponen Indikator Keterampilan Proses Sains

\begin{tabular}{|c|c|}
\hline \multicolumn{2}{|c|}{$\begin{array}{c}\text { Keterampilan Proses Sains } \\
\text { (Science Process Skills) }\end{array}$} \\
\hline $\begin{array}{l}\text { Keterampilan proses sains dasar } \\
\text { (Basic Science Process Skills) }\end{array}$ & $\begin{array}{c}\text { Keterampilan proses sains terintegrasi } \\
\text { (Integrated Science Process Skills) }\end{array}$ \\
\hline $\begin{array}{l}\text { 1. Observasi } \\
\text { 2. Memprediksi } \\
\text { 3. Menggolongkan } \\
\text { 4. Mengukur } \\
\text { 5. Menyimpulkan } \\
\text { 6. Mengkomunikasikan }\end{array}$ & $\begin{array}{l}\text { 1. Membangun hipotesis } \\
\text { 2. Mendesain penelitian } \\
\text { 3. Eksperimen } \\
\text { 4. Memperoleh dan memproses data } \\
\text { 5. Mengidentifikasi variabel } \\
\text { 6. Mendefinisikan variabel } \\
\text { 7. Mendeskripsikan hubungan antar variabel } \\
\text { 8. Membuat tabel } \\
\text { 9. Membuat grafik } \\
\text { 10. Menganalisis penelitian }\end{array}$ \\
\hline
\end{tabular}

(Rezba dkk, 2006: 4-6)

Keterampilan proses sains sangat diperlukan untuk diterapkan dalam pembelajaran karena perkembangan pengetahuan yang terus berkembang, Letsholo \& Yandila (2002) yang menjelaskan perlunya pengembangan keterampilan proses sains karena 1) perkembangan ilmu pengetahuan berlangsung semakin cepat; 2) anak-anak mudah memahami konsep yang rumit dan abstrak jika disertai dengan contohcontoh konkrit; 3) penemuan ilmu pengetahuan tidak mutlak benar 100\%, artinya penemuan bersifat relatif; 4) dalam proses pembelajaran sebaiknya pengembangan konsep tidak dilepaskan dari pengembangan sikap dan nilai dalam diri siswa.

Penelitian ini dilakukan di SMA Negeri 7 Malang pada materi Kalor. Dipilihnya materi kalor dikarenakan 1) materi kalor diberikan pada semester genap sesuai dengan rencana penelitian; 2) penerapan materi kalor banyak berkaitan dengan kehidupan sehari-hari; 3) dapat diimplementasikan dalam kegiatan laboratorium, sehingga dapat mengembangkan keterampilan proses siswa. Dalam penelitian ini kelas eksperimen menggunakan strategi 
REACT dan pembelajaran konvensional pada kelas kontrol.

\section{METODE PENELITIAN}

Penelitian ini dilaksanakan di SMA Negeri 7 Malang yang terletak di Jalan Cengger Ayam I/14 Malang. Populasi dalam penelitian ini adalah seluruh siswa kelas X SMA Negeri 7 Malang 400 siswa. Sampel yang digunakan dalam penelitian sebanyak empat kelas dengan 156 siswa, yang dipilih berdasarkan purposive sampling sehingga terdiri atas 2 kelas eksperimen dan kontrol. Desain penelitian ini menggunakan rancangan penelitian kuasi-eksperimen. Kelas eksperimen dan kontrol masing-masing terdiri atas 78 siswa. Sampel yang digunakan pada penelitian melibatkan 33,3\% siswa dengan keterampilan proses sains tinggi dan 33,3\% siswa dengan keterampilan proses sains rendah. Jumlah sampel yang digunakan adalah 104 siswa. Penelitian ini dilaksanakan dalam 4 kali pertemuan. Waktu yang dibutuhkan sekali pertemuan adalah $2 \times 45$ menit.

Instrumen perlakuan dalam penelitian ini meliputi rancangan pelaksanaan pembelajaran (RPP) dan lembar kerja siswa (LKS). Instrumen pengukuran yang digunakan dalam penelitian adalah perangkat pembelajaran yang terdiri atas lembar keterlaksanaan RPP, instrumen keterampilan proses sains, dan instrumen untuk mengukur prestasi belajar fisika kognitif. Data keterampilan proses sains dinilai dengan menggunakan lembar observasi. Komponen penilaiannya terdiri atas; 1) bereksperimen, 2) mengukur, 3) membuat tabel, 4) memeperoleh data, 5) memproses data, dan 6) membuat kesimpulan. Data prestasi belajar diperoleh dari nilai prestasi belajar.

Data yang diperoleh dalam penelitian diawali dengan mengukur keterampilan proses siswa yang menggunakan lembar observasi. Skala yang digunakan dalam penelitian keterampilan proses sains adalah skala
Likert yaitu 1, 2, 3, dan 4. Nilai keterampilan proses sains yang diperoleh dalam penelitian dapat mengelompokkan siswa yang memiliki keterampilan proses sains tinggi dengan rendah. Perlakuan diberikan setelah melakukan penilaian keterampilan proses, perlakuan yang diberikan di kelas eksperimen dengan menerapkan pembelajaran strategi REACT dan pembelajaran pada kelas kontrol diterapkan secara konvensional atau pembelajaran yang biasa diterapkan oleh guru di sekolah. Setelah semua materi kalor diberikan maka dilakukan tes prestasi belajar fisika dengan memberikan tes 20 soal pilihan ganda. Soal C1 terdiri dari 2 soal, soal C2 terdiri dari7 soal, soal C3 terdiri dari 6 soal, dan soal C4 terdiri dari 5 soal.

Rancangan penelitian yang digunakan adalah rancangan eksperimen semu (Quasi Experimental Design). Rancangan penelitian yang digunakan adalah rancangan faktorial $2 \times 2$. Adapun bentuk rancangan eksperimen ditunjukkan pada Tabel 2.

Tabel 2. Desain Eksperimen

\begin{tabular}{ccc}
\hline $\begin{array}{c}\text { Keterampilan } \\
\text { proses sains }\end{array}$ & \multicolumn{2}{c}{ Strategi Pembelajaran } \\
\cline { 2 - 3 } & $\begin{array}{c}\text { REACT } \\
\left(\mathbf{A}_{\mathbf{1}}\right)\end{array}$ & $\begin{array}{c}\text { Konvensional } \\
\left(\mathbf{A}_{2}\right)\end{array}$ \\
\hline Tinggi $\left(\mathrm{B}_{1}\right)$ & $\left(\mathrm{A}_{1} \mathrm{~B}_{1}\right)$ & $\left(\mathrm{A}_{2} \mathrm{~B}_{1}\right)$ \\
\hline Rendah $\left(\mathrm{B}_{2}\right)$ & $\left(\mathrm{A}_{1} \mathrm{~B}_{2}\right)$ & $\left(\mathrm{A}_{2} \mathrm{~B}_{2}\right)$ \\
\hline
\end{tabular}

Keterangan:

$\left(\mathrm{A}_{1} \mathrm{~B}_{1}\right)=$ Prestasi belajar fisika siswa yang belajar dengan strategi REACT dan memiliki keterampilan proses sains tinggi

$\left(\mathrm{A}_{2} \mathrm{~B}_{1}\right)=$ Prestasi belajar fisika siswa yang belajar secara konvensional dan memiliki keterampilan proses sains tinggi

$\left(\mathrm{A}_{1} \mathrm{~B}_{2}\right)=$ Prestasi belajar fisika siswa yang belajar dengan strategi REACT dan memiliki keterampilan proses sains rendah

$\left(\mathrm{A}_{2} \mathrm{~B}_{2}\right)=$ Prestasi belajar fisika siswa yang belajar secara konvensional dan memiliki keterampilan proses sains rendah 
Sebelum digunakan, instrumen tes prestasi belajar fisika telah diuji cobakan terlebih dahulu untuk mengetahui: 1) taraf kesukaran; 2) daya beda; 3) validitas; dan 4) reliabilitas. Analisis statistik yang digunakan terdiri atas uji prasyarat (uji normalitas dan homogenitas) dan uji hipotesis (uji ANAVA 2 jalur dan uji Tukey). Dalam penelitian ini uji normalitas, homogenitas, dan ANAVA dua jalur menggunakan SPSS 16.0 for Windows. Rumus uji Tukey yang digunakan ditunjukkan pada Persamaan 1 (Murwani, 2001:63) berikut ini.

$$
Q=\frac{|\overline{X i}-\overline{\lambda]}|}{\sqrt{\frac{R K D}{n}}}
$$

\section{Keterangan:}

$\mathrm{Q} \quad=$ angka Tukey

$\mathrm{X} \mathrm{i}=$ rata-rata data kelompok $\mathrm{i}$

$\mathrm{X} \mathrm{j} \quad=$ rata-rata data kelompok $\mathrm{j}$

$\mathrm{RKD}=$ rata-rata kuadrat dalam

$\mathrm{n} \quad=$ banyak data tiap kelompok $(\mathrm{ni}=\mathrm{nj})$
HASIL DAN PEMBAHASAN

\section{Hasil Penelitian}

\section{Data Keterampilan Proses Sains}

Penelitian yang dilakukan tidak dapat mengukur keseluruhan komponen keterampilan proses sains, dikarenakan penilaian yang dilakukan menggunakan lembar observasi, sehingga komponen yang dinilai dibatasi. Skala penilaian yang digunakan menggunakan menggunakan skala Likert yaitu 1, 2, 3, dan 4. Keterampilan proses sains yang diukur terdiri dari 2 komponen keterampilan proses sains dasar yaitu mengukur dan menyimpulkan, dan 3 komponen keterampilan terintegrasi yaitu eksperimen, memperoleh dan memproses data, serta membuat tabel.

$$
\text { Lima komponen keterampilan }
$$
proses sains yang akan dinilai dikembangkan menjadi 6 komponen, yaitu: 1) eksperimen; 2) mengukur; 3) membuat tabel; 4) memperoleh data; 5) memproses data; 6) menyimpulkan. Tiap komponen keterampilan proses sains yang dimiliki siswa bervariasi. Berikut adalah Tabel 3 yang menyajikan persentase rata-rata kelas tiap komponen keterampilan proses.

Tabel 3. Persentase Rata-Rata Komponen Keterampilan Proses Sains

\begin{tabular}{ccc}
\hline Komponen KPS & $\begin{array}{c}\text { Rata-rata } \\
\text { Kelas Eksperimen }\end{array}$ & $\begin{array}{c}\text { Rata-rata } \\
\text { Kelas Kontrol }\end{array}$ \\
\hline Eksperimen & $77,56 \%$ & $71,47 \%$ \\
\hline Mengukur & $63,14 \%$ & $60,58 \%$ \\
\hline Membuat tabel & $62,82 \%$ & $57,05 \%$ \\
\hline Memproses data & $71,47 \%$ & $69,87 \%$ \\
\hline Memperoleh data & $66,67 \%$ & $67,31 \%$ \\
\hline Menyimpulkan & $52,24 \%$ & $56,09 \%$ \\
\hline
\end{tabular}

Data keterampilan proses sains diperoleh pada saat siswa berproses dengan teman kelompoknya yang berjumlah 4 orang. Materi pada saat menilai keterampilan proses sains adalah materi sebelum kalor, yaitu optik. Hal ini dilakukan agar siswa dapat melakukan keterampilan proses sains dengan mandiri, karena materi pembelajarannya sudah dipelajari oleh siswa.

Nilai keterampilan proses sains yang diperoleh menjadi acuan untuk mengelompokkan sampel ke dalam siswa dengan keterampilan proses tinggi dan rendah. Pengelompokan nilai keterampilan proses sains dibuat persentase $33,3 \%$ dari nilai kelompok 
keterampilan proses sains tinggi dan 33,3\% dari nilai kelompok keterampilan proses sains rendah. Jumlah siswa pada kelas ekaperimen dan kelas kontrol masing-masing adalah 78 siswa. 33,3\% dari 78 siswa yang dikelompokkan diperoleh 26 siswa dengan keterampilan proses sains tinggi pada kelas eksperimen dan kelas kontrol, dan 26 siswa dengan keterampilan proses sains rendah pada kelas eksperimen dan kelas kontrol.

\section{Data Prestasi Belajar Fisika}

Data prestasi belajar fisika diperoleh dari tes pilihan ganda dari 20 soal. Soal prestasi belajar telah divalidasi isi oleh dua dosen ahli, selain di validasi isi soal juga harus di uji coba terlebih dahulu. Soal prestasi belajar fisika yang dirancang pada saat di validasi isi dan uji coba berjumlah 30 soal yang disesuaikan dengan indikator pembelajaran materi suhu dan kalor. Setelah uji coba soal, soal di analisis validitas dan reliabilitas, sehingga diperoleh 22 soal yang valid dengan nilai reliabiltas 0,740 .

\section{Data Uji ANAVA Dua Arah}

Penyajian data uji ANAVA 2 jalur dapat dilihat pada Tabel 4.

Tabel 4. Ringkasan Uji ANAVA 2 Jalur Prestasi Belajar Fisika

\begin{tabular}{|c|c|c|c|c|c|c|c|}
\hline Source & $\begin{array}{l}\text { Type III } \\
\text { Sum of } \\
\text { Square }\end{array}$ & df & $\begin{array}{c}\text { Mean } \\
\text { Square }\end{array}$ & $\mathbf{F}$ & Sig. & $\begin{array}{c}F_{\text {tabel }} \\
(3: 100)\end{array}$ & $\begin{array}{c}F_{\text {tabel }} \\
(1: 100)\end{array}$ \\
\hline Corrected Model & $1484.231 *$ & 3 & 494.744 & 135.261 & .000 & 2,7 & 3,94 \\
\hline Intercept & 13754.000 & 1 & 13754.000 & $3.760 \mathrm{E} 3$ & .000 & & \\
\hline Kelas & 34.615 & 1 & 34.615 & 9.464 & .003 & & \\
\hline KPS & 1432.654 & 1 & 1432.654 & 391.682 & .000 & & \\
\hline Kelas * KPS & 16.962 & 1 & 16.962 & 4.637 & .034 & & \\
\hline Error & 365.769 & 100 & 3.658 & & & & \\
\hline Total & 15604.000 & 104 & & & & & \\
\hline Corrected Total & 1850.000 & 103 & & & & & \\
\hline
\end{tabular}

a. $\quad$ R Squared $=.802$ (Adjusted R Squared $=.796)$

Penjelasan hasil analisis dengan menggunakan SPSS pada Tabel 3 dijabarkan berikut ini.

1. $\mathrm{F}_{\text {hitung }}=9,46>\mathrm{F}_{\text {tabel }}=3,94$, maka dapat disimpulkan bahwa ada perbedaan prestasi belajar fisika antara siswa yang belajar dengan strategi REACT dengan siswa yang belajar secara konvensional.

2. $\mathrm{F}_{\text {hitung }}=391,68>\mathrm{F}_{\text {tabel }}=3,94$, maka dapat disimpulkan bahwa ada perbedaan prestasi belajar fisika antara siswa yang memiliki keterampilan proses sains tinggi dengan siswa yang memiliki keterampilan proses sains rendah.

3. $F_{\text {hitung }}=4,64>F_{\text {tabel }}=3,94$, maka dapat disimpulkan bahwa terdapat interaksi antara strategi pembelajaran dan keterampilan proses sains terhadap prestasi belajar fisika.
4. Karena terdapat perbedaan, maka analisis dilanjutkan dengan uji Tukey.

Hasil penelitian menunjukkan terdapat perbedaan prestasi belajar fisika sebagai akibat penerapan strategi pembelajaran yang berbeda. Dari data penelitian dapat dikatakan bahwa terdapat interaksi antara strategi pembelajaran dengan keterampilan proses sains terhadap prestasi belajar fisika. Antara strategi pembelajaran dan keterampilan proses sama-sama memberikan sumbangan terhadap prestasi belajar fisika.

Rata-rata prestasi belajar siswa dengan keterampilan proses sains tinggi dan rendah pada kelas dengan pembelajaran konvensional dan kelas dengan strategi REACT dapat dilihat pada Gambar 1. Pada Gambar 1 apabila 
kedua garis diperpanjang maka terdapat perpotongan antara dua garis, yang menunjukkan adanya interaksi antara strategi pembelajaran dan keterampilan proses sains terhadap hasil belajar.

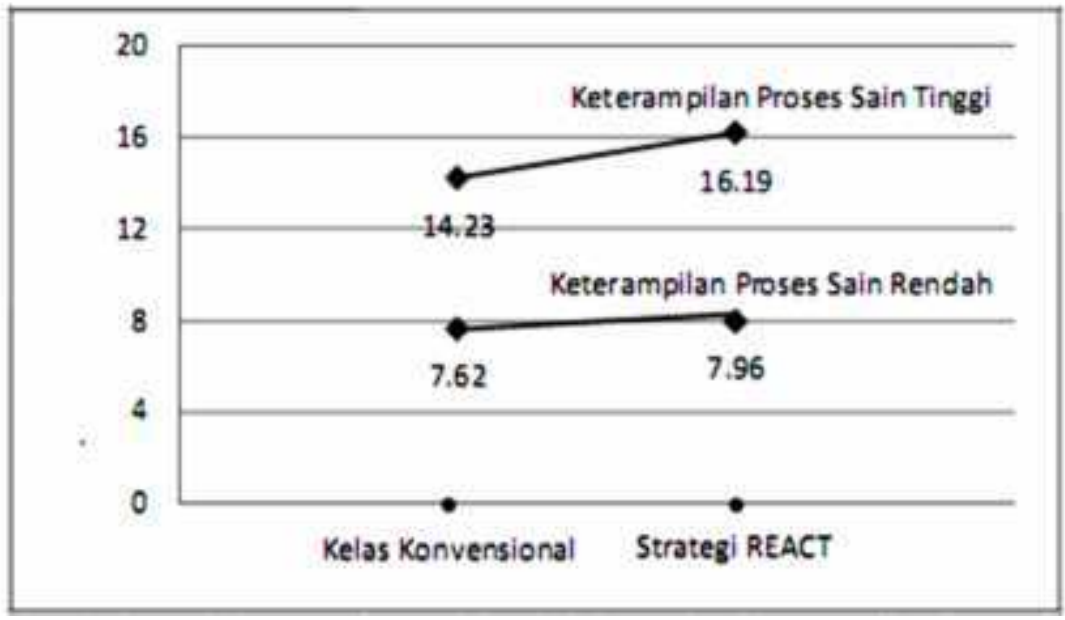

Gambar 1. Interaksi antara Strategi Pembelajaran dan

KeterampilanProses Sains terhadap Prestasi Belajar Fisika

Penerapan strategi pembelajaran yang baik dapat mengembangkan keterampilan proses sains siswa sehingga dapat mendukung terciptanya prestasi belajar yang baik. Maka dapat disimpulkan bahwa keterampilan proses sains berpengaruh terhadap prestasi belajar siswa. Menurut Hindriani (2007) pemilihan model pembelajaran merupakan suatu hal yang penting untuk menentukan kualitas pembelajaran. Belajar akan lebih bermakna jika anak mengalami apa yang dipelajari, bukan hanya mengetahui.

Hasil penelitian yang relevan dengan penelitian ini adalah penelitian yang dilakukan oleh Suandi (2006: 1079-1094) yang menunjukkan adanya interaksi antara model pembelajaran dan pengetahuan awal terhadap hasil belajar pengantar akuntansi. Namun hasil penelitian ini berkebalikan dengan penelitian yang dilakukan oleh Suandi dan Pranata (2010:98-105) yang menunjukkan tidak adanya interaksi antara model pembelajaran dengan prior knowledge mahasiswa terhadap hasil belajar mata kuliah sistem akuntansi.

\section{Uji ANAVA Dua Jalur antara $A_{1}$ dan $A_{2}$ untuk $B_{1}$ \\ Uji perbedaan prestasi belajar} fisika kelas strategi REACT dan kelas konvensional untuk siswa yang memiliki keterampilan proses sains tinggi. Data uji ANAVA dua jalur antara A1 dan A2 untuk B1 dapat dilihat pada Tabel 5.

Tabel 5. Data Uji ANAVA Dua Jalur antara $A_{1}$ dan $A_{2}$ untuk $B_{1}$

\begin{tabular}{ccccccc}
\hline $\begin{array}{c}\text { SUMBER } \\
\text { VARIAN }\end{array}$ & $\mathbf{J K}$ & $\mathbf{d k}$ & $\mathbf{R J K}$ & Fhitung & $\begin{array}{c}\mathbf{F} \text { Tabel } \\
\mathbf{( 5 \% )}(\mathbf{1 ;} \mathbf{5 0})\end{array}$ & Kesimpulan \\
\hline Antar A & 50,02 & 1 & 50,02 & 12,34 & 4,03 & $12,34>4,03$ \\
Dalam & 202,65 & 50 & 4,05 & & & $\mathrm{H}_{0}$ diterima \\
Total & 252,67 & 51 & & & & \\
\hline
\end{tabular}

Tabel 5 menunjukkan bahwa Fhitung lebih besar daripada $F_{\text {tabel }}(12,34>4,03)$ maka $\mathrm{H}_{1}$ diterima yang artinya ada perbedaan prestasi belajar fisika antara kelas strategi REACT dan kelas 
konvensional pada siswa dengan keterampilan proses sains tinggi.

\section{Uji ANAVA Dua Jalur antara $A_{1}$ dan $A_{2}$ pada $B_{2}$}

Uji perbedaan prestasi belajar fisika kelas strategi REACT dan kelas konvensional untuk siswa dengan keterampilan proses sains rendah. Data uji ANAVA dua jalur antara A1 dan A2 untuk B2 dapat dilihat pada Tabel 6 .

Tabel 6. Data Uji ANAVA Dua Jalur antara $A_{1}$ dan $A_{2}$ untuk $B_{2}$

\begin{tabular}{ccccccc}
\hline $\begin{array}{c}\text { SUMBER } \\
\text { VARIAN }\end{array}$ & $\mathbf{J K}$ & $\mathbf{D k}$ & $\mathbf{R J K}$ & Fhitung & $\begin{array}{c}\mathbf{F}_{\text {Tabel }} \\
(\mathbf{5 \%}) \mathbf{( 1 ;} \mathbf{5 0 )}\end{array}$ & Kesimpulam \\
\hline Antar A & 1,56 & 1 & 1,56 & 0,48 & 4,03 & $0,48>4,03$ \\
Dalam & 163,12 & 50 & 3,26 & & & $\mathrm{H}_{0}$ diterima \\
Total & 164,67 & 51 & & & & \\
\hline
\end{tabular}

Tabel 6 menunjukkan bahwa Fhitung lebih kecil daripada $\mathrm{F}_{\text {tabel }}(0,48>$ 4,03) maka $\mathrm{H}_{0}$ diterima yang artinya tidak ada perbedaan prestasi belajar fisika antara kelas strategi REACT dan kelas konvensional pada siswa dengan keterampilan proses sains rendah.

\section{Data Uji Hipotesis dengan Uji Tukey \\ Data keseluruhan dari uji Tukey dapat dilihat pada Tabel 7.}

Tabel 7. Penyajian Data Uji Tukey

\begin{tabular}{lcccc}
\multicolumn{1}{c}{ Data yang diuji } & Qhitung & Qtabel & N & Sig \\
\hline Antara A1 dan A2 & 4,35 & 3,74 & 52 & $5 \%$ \\
Antara B1 dan B2 & 55,96 & 4,74 & 52 & \\
Antara A1 dan A2 untuk B1 & 5,23 & 3,90 & 26 & \\
Antara A1 dan A2 untuk B2 & 0,92 & 3,90 & 26 & \\
Antara B1 dan B2 untuk A1 & 21,94 & 3,90 & 26 & \\
Antara B1 dan B2 untuk A2 & 17,63 & 3,90 & 26 & \\
Antara A1 B1 dan A2 B2 & 22,86 & 3,90 & 26 & \\
Antara A2 B1 dan A1 B2 & 16,71 & 3,90 & 26 & \\
\hline
\end{tabular}

\section{Pembahasan}

\section{Pengaruh Strategi Pembelajaran} REACT dan Pembelajaran Konvensional terhadap Prestasi Belajar Fisika

Analisis uji Tukey menunjukkan pada Tabel $7 \mathrm{Q}_{\mathrm{H}}=4,35>\mathrm{Q}_{\mathrm{T}}=3,74$, maka $\mathrm{H}_{0}$ ditolak dan $\mathrm{H}_{1}$ diterima. Dari hasil analisis maka dapat disimpulkan bahwa prestasi belajar fisika siswa yang belajar dengan strategi REACT lebih tinggi daripada prestasi belajar fisika siswa yang belajar secara konvensional.

Hasil penelitian menunjukkan terdapat perbedaan prestasi belajar fisika yang signifikan setelah dilakukan pembelajaran dengan strategi pembelajaran yang berbeda. Analisis lebih lanjut yang dapat dikemukakan adalah prestasi belajar fisika siswa yang belajar dengan strategi REACT lebih tinggi dibanding dengan siswa yang belajar secara konvensional. Prestasi belajar merupakan hasil dari interaksi tindakan belajar dan tindakan mengajar. Apabila strategi REACT diterapkan dalam pembelajaran dapat mempengaruhi prestasi belajar siswa (Dimyati, 2006:55). Pembelajaran dengan strategi REACT dapat membuat prestasi belajar fisika siswa lebih tinggi dari pada siswa yang belajar secara konvensional karena selain melakukan percobaan siswa juga diberikan permasalahan-permasalahan 
yang dapat melatih pemahaman siswa, serta menghubungkan konteks kehidupan sehari-hari dengan materi pembelajaran.

Hasil penelitian yang relevan dengan penelitian ini adalah penelitian yang dilakukan oleh Sudibyo (2008:715) dinyatakan bahwa pembelajaran kontekstual dapat memotivasi siswa dan menuntaskan prestasi belajar fisika pada siswa kelas VIII-A SMPN 3 Porong. Senada dengan Sudibyo, Sakdiyah (2009: 34-40) menyimpulkan bahwa terdapat perbedaan yang signifikan antara prestasi belajar siswa pada pokok bahasan pasar modal yang diajarkan menggunakan pendekatan kontekstual dan metode konvensional kelas II IPS SMAN 8 Banda Aceh. Suandi (2006:1079-1094) menunjukkan adanya perbedaan hasil belajar akuntansi antara mahasiswa yang belajar dengan model konstruktivis dan konvensional. Penelitian yang dilakukan Suandi dan Pranata (2010:98-105) menjelaskan bahwa terdapat perbedaan hasil belajar yang signifikan antara kelompok mahasiswa yang menggunakan cooperative learning dengan kelompok mahasiswa yang menggunakan model pembelajaran konvensional.

Strategi REACT merupakan strategi penerapan pembelajaran kontekstual (Crawford, 2001:3-15), dan pembelajaran kontekstual atau Contekstual Teaching and Learning (CTL) berkembang dari faham konstruktivis (Nugroho, 2010:113). Strategi REACT merupakan strategi yang digunakan untuk menerapkan pembelajaran kontekstual, "Center of Occupational Research and Development (CORD) menyampaikan 5 (lima) strategi bagi pendidik dalam rangka menerapkan pembelajaran kontekstual yang biasa disingkat dengan REACT" (Hindriana, 2007:58). Dalam pembelajaran guru harus pandai memilih dan menerapkan strategi pembelajaran, sehingga dalam proses pembelajaran sampai akhir tujuan pembelajaran dapat tercapai.

\section{Interaksi antara Strategi \\ Pembelajaran dan Keterampilan \\ Proses Sains terhadap Prestasi \\ Belajar Fisika}

Hasil penelitian menunjukkan terdapat perbedaan prestasi belajar fisika sebagai akibat penerapan strategi pembelajaran yang berbeda. Dari data penelitian dapat dikatakan terdapat interaksi antara strategi pembelajaran dengan keterampilan proses sains terhadap prestasi belajar fisika. Antara strategi pembelajaran dan keterampilan proses sama-sama memberikan sumbangan terhadap prestasi belajar fisika.

Rata-rata hasil belajar siswa dengan keterampilan proses sains tinggi dan rendah pada kelas dengan pembelajaran konvensional dan kelas dengan strategi REACT dapat dilihat pada Gambar 1. Pada Gambar 1 apabila kedua garis diperpanjang maka terdapat perpotongan antara dua garis, yang menunjukkan adanya interaksi antara strategi pembelajaran dan keterampilan proses sains terhadap hasil belajar.

Penerapan strategi pembelajaran yang baik dapat mengembangkan keterampilan proses sains siswa sehingga dapat mendukung terciptanya prestasi belajar yang baik. Maka dapat disimpulkan bahwa keterampilan proses sains berpengaruh terhadap prestasi belajar siswa. Menurut Hindriani (2007) pemilihan model pembelajaran adalah hal yang penting untuk menentukan kualitas pembelajaran. Belajar akan lebih bermakna jika anak mengalami apa yang dipelajari, bukan hanya mengetahui.

Hasil penelitian yang relevan dengan penelitian ini adalah penelitian yang dilakukan oleh Suandi yang menunjukkan adanya interaksi antara model pembelajaran dan pengetahuan awal terhadap hasil belajar pengantar akuntansi (2006:1079-1094). Namun hasil penelitian ini berkebalikan dengan penelitian yang dilakukan oleh Suandi dan Pranata (2010:98-105) yang 
menunjukkan tidak adanya interaksi antara model pembelajaran dengan prior knowledge mahasiswa terhadap hasil belajar mata kuliah sistem akuntansi.

\section{Pengaruh Strategi Pembelajaran REACT terhadap Prestasi Belajar Fisika Siswa yang Memiliki Keterampilan Proses Sains Tinggi}

Analisis uji Tukey menunjukkan pada Tabel $7 \mathrm{Q}_{\mathrm{H}}=5,23>\mathrm{Q}_{\mathrm{T}}=3,90$, maka $\mathrm{H}_{0}$ ditolak dan $\mathrm{H}_{1}$ diterima. Dari hasil analisis maka dapat disimpulkan bahwa prestasi belajar fisika siswa yang mempunyai keterampilan proses sains tinggi belajar dengan strategi REACT lebih tinggi daripada siswa yang belajar secara konvensional.

Hasil penelitian melalui uji ANAVA 2 jalur menunjukkan terdapat perbedaan yang signifikan terhadap prestasi belajar fisika siswa yang belajar dengan strategi REACT dan yang belajar secara konvensional pada siswa yang memiliki keterampilan proses sains rendah. Kesimpulan lebih lanjut yang dapat dikemukakan yaitu prestasi belajar fisika siswa memiliki keterampilan proses sains tinggi, lebih tinggi jika belajar dengan strategi REACT dibanding dengan siswa yang belajar secara konvensional.

Strategi REACT adalah strategi pembelajaran yang dikembangkan untuk dapat membantu mengembangkan pemahaman siswa yang mendalam terhadap konsep-konsep fundamental yang didasarkan pada penelitian. Rustaman (2005:86) menunjukkan bahwa keterampilan proses perlu dikembangkan melalui pengalaman langsung, sebagai pengalaman belajar dan disadari ketika kegiatannya sedang berlangsung. Dengan keterampilan proses sains pengalaman siswa pada suatu konsep akan lebih bermakna, dengan stratergi pembelajaran guru dapat mengembangkan keterampilan proses sains. Pemilihan model pembelajaran merupakan suatu hal yang penting untuk menentukan kualitas pembelajaran. Belajar akan lebih bermakna jika anak mengalami apa yang dipelajari, bukan hanya mengetahui (Hindriana, 2007:55). Sehingga dengan penerapan strategi REACT pada siswa yang memiliki keterampilan proses sains tinggi maka dapat mempengaruhi prestasi belajar fisika siswa.

Hasil penelitian yang relevan dengan penelitian ini adalah penelitian yang dilakukan oleh Rahayu (2011) yang menunjukkan adanya perbedaan yang signifikan antara prestasi belajar dan kemampuan berpikir kreatif siswa yang belajar dengan menggunakan pendekatan keterampilan proses. Namun hasil penelitian yang dilakukan berkebalikan dengan hasil penelitian yang dilakukan oleh Susiwi, dkk (2009) yang menunjukkan adanya pembelajaran MPP D-E-H, keterampilan "merumuskan hipotesis", keterampilan "mengendalikan variabel" dan keterampilan "merancang percobaan" dapat dikembangkan pada kelompok SMA dengan prestasi akademik sedang maupun kelompok SMA dengan prestasi akademik tinggi.

Penelitian lainnya yang setara dengan penelitian ini adalah penelitian yang dilakukan oleh Suandi serta Pranata dan Suandi. Namun perbandingan yang dilakukan tidak sama. Penelitian Suandi (2006:1079-1094) menunjukkan hasil belajar kelompok mahasiswa yang memiliki pengetahuan awal tinggi, lebih tinggi dari kelompok mahasiswa yang memiliki pengetahuan awal rendah. Selain itu, penelitian yang dilakukan Suandi dan Pranata (2010:98-105) menjelaskan bahwa hasil belajar kelompok mahasiswa yang memiliki prior knowledge tinggi, lebih tinggi dari kelompok mahasiswa yang memiliki prior knowledge rendah. 
4. Pengaruh Strategi Pembelajaran REACT terhadap Prestasi Belajar Fisika Siswa yang Memiliki Keterampilan Proses Sains Rendah

Analisis uji Tukey menunjukkan $\mathrm{Q}_{\mathrm{H}}=0,92<\mathrm{Q}_{\mathrm{T}}=3,90$, maka $\mathrm{H}_{0}$ diterima dan $\mathrm{H}_{1}$ ditolak. Dari hasil analisis maka dapat disimpulkan bahwa prestasi belajar fisika siswa yang mempunyai keterampilan proses sains rendah belajar secara konvensional lebih tinggi daripada siswa yang belajar dengan strategi REACT yang mempunyai keterampilan proses sains rendah.

Hasil penelitian melalui uji ANAVA 2 jalur menunjukkan tidak ada perbedaan yang signifikan terhadap prestasi belajar fisika siswa yang belajar dengan strategi REACT dan yang belajar secara konvensional pada siswa yang memiliki keterampilan proses sains rendah. Kesimpulan lebih lanjut yang dapat dikemukakan adalah prestasi belajar fisika siswa yang mempunyai keterampilan proses sains rendah yang belajar secara konvensional tidak berbeda dengan siswa yang belajar dengan strategi REACT.

Hasil penelitian yang relevan dengan penelitian ini adalah penelitian yang dilakukan oleh Suandi (2006:10791094) yang menunjukkan hasil belajar kelompok mahasiswa yang memiliki pengetahuan awal rendah lebih baik diberikan model pembelajaran konvensional dibandingkan dengan model pembelajaran konstruktivis. Kecenderungan yang terjadi adalah siswa yang memiliki keterampilan proses sains rendah nilai prestasi belajar fisika siswa yang belajar secara konvensional akan lebih tinggi daripada siswa yang memilki keterampilan proses sains rendah yang belajar dengan strategi REACT. Siswa dengan keterampilan proses sains rendah menandakan bahwa siswa cenderung pasif pada saat proses pembelajaran, sehingga meskipun dalam proses pembelajaran menerapkan pembelajaran yang aktif siswa masih cenderung pasif dalam pembelajaran. Siswa yang pasif cenderung lebih nyaman dengan pembelajaran konvensional, karena tidak perlu berperilaku aktif dalam pembelajaran.

Wynne Harlen dalam Wartono (2010:29) mengemukakan bahwa keterampilan proses merupakan hasil kognitif kehidupan siswa pada umumnya, pengembangannya menolong siswa untuk belajar, dan kegiatan ilmiah yang kelihatan baik di sekolah maupun di kemudian hari, tergantung pada keterampilan-keterampilan proses sains. Kemandirian siswa mulai dilatih selama proses pembelajaran. Kemandirian siswa terlihat dari adanya tanya jawab antara guru dengan siswa, antara siswa dengan siswa teman kelompoknya. Selain kemandirian siswa diajak untuk belajar bersosialiasi, yaitu guru membentuk kelompok belajar dalam rangka memberi kesempatan kepada siswa untuk belajar dengan sesama temannya.

Hasil penelitian menunjukkan adanya pengaruh terhadap prestasi belajar fisika siswa yang belajar dengan strategi REACT dan memiliki keterampilan proses sains rendah, maka dengan mengembangkan keterampilan proses sains akan mempengaruhi prestasi belajar fisika siswa. Rambuda \& Fraser (2004) menunjukkan bahwa guru Geografi harus melakukan beberapa percobaan sederhana di kelas untuk menunjukkan pada siswa keterampilan proses terintegrasi. sehingga untuk mengembangkan keterampilan proses sains guru membimbing siswa melakukan keterampilan proses, baik pada siswa yang memiliki keterampilan proses tinggi ataupun pada siswa yang memiliki keterampilan proses rendah.

Berdasarkan hasil penelitian yang dilakukan dapat diketahui bahwa strategi REACT memiliki beberapa kelebihan. Kelebihan pembelajaran strategi REACT yaitu: 1) strategi REACT menjadikan siswa lebih aktif dalam proses pembelajaran karena siswa melakukan 
penelitian; 2) strategi REACT menjadikan siswa lebih kreatif karena mereka tidak hanya belajar dari buku pelajaran saja, tetapi mereka juga belajar dari lingkungan sekitar; 3) strategi REACT lebih meningkatkan kerjasama antar siswa, karena pembelajaran dilakukan dengan sistem kerja kelompok; 4) strategi REACT dapat mensiasati keterbatasan alat percobaan dengan melakukan percobaan secara berkelompok.

\section{PENUTUP \\ Kesimpulan}

Kesimpulan dari penelitian ini adalah prestasi belajar fisika siswa yang belajar dengan strategi REACT lebih tinggi daripada siswa yang belajar secara konvensional. Terdapat interaksi antara strategi pembelajaran dan keterampilan proses sains terhadap prestasi belajar fisika siswa. Siswa dengan keterampilan proses sains tinggi dan belajar dengan strategi REACT memiliki nilai prestasi belajar fisika lebih tinggi daripada siswa yang belajar secara konvensional. Siswa dengan keterampilan proses sains rendah dan belajar secara konvensional memiliki prestasi belajar fisika lebih tinggi daripada siswa yang belajar dengan strategi REACT.

\section{Saran}

Berdasarkan penelitian yang telah dilaksanakan, saran yang dapat diberikan adalah hasil penelitian dengan menerapkan strategi REACT menunjukkan hasil prestasi belajar fisika yang lebih baik dari pembelajaran konvensional. Oleh sebab itu, strategi REACT dapat digunakan sebagai alternatif bagi guru kelas $\mathrm{X}$ untuk meningkatkan prestasi belajar siswa. Strategi REACT dapat diterapkan pada materi yang berbeda dalam fisika, sehingga pembelajaran fisika dapat lebih aktif.

\section{DAFTAR PUSTAKA}

CORD. 2003. The REACT Strategy (online), (http:www.texascollabora te.org/The REACT Strategi.html. diakses 29-09-11).

Crawford, Michael L. 2001. Teaching Contextually. Texas: CCI Publishing, Inc.

Dimyati \& Mujiono. 2006. Belajar dan Pembelajaran. Jakarta: Rineka Cipta.

Fauziah, Anna. 2010. Peningkatan Kemampuan Pemahaman Dan Pemecahan Masalah Matematik Siswa SMP Melalui Strategi REACT (Relating, Experiencing, Applying, Cooperating, Transferring). Tesis tidak diterbitkan: Bandung: Universitas Pendidikan Indonesia.

Hindriana, Anna Fitri. 2007. Pembelajaran dan Pengajaran Kontekstual. Equilibrium, 3(5): 5461.

Hidayat, Rachmat. 2010. Pembelajaran Kontekstual dengan Strategi REACT dalam Upaya Pengembangan Kemampuan Pemecahan Masalah, Berpikir Kritis, dan Berpikir Kreatif Matematis Mahasiswa Bidang Bisnis. Disertasi tidak diterbitkan: Bandung: Universitas Pendidikan Indonesia.

Letsholo, D. \& Yandila, C.D. 2002. Process Skills in Botswana Primary SchoolScience Lessons. University of Botswana, (Online), (http:// www.ufes.br/xioste/ papers/xioste paper008.pdf, diakses 03-04-11).

Margono, Hadi, Balqis, dan Wulandari, Dewi. 2007. Pembelajaran di Luar Kelas dengan Strategi REACT untuk Materi Pengelolaan Lingkungan Sebagai Tindakan Meningkatkan Motivasi dan Prestasi Belajar Siswa Kelas VII SMP Negeri 4 Malang. Chimera, 12(1):1-14. 
Marthen, Tapilouw. 2010. Pembelajaran Melalui Pendekatan REACT Meningkatkan Kemampuan Matematis Siswa SMP. Jurnal Penelitian Pendidikan, 11(2):129141.

Murwani, Santosa. 2001. Statistika Terapan (Teknik Analisis Data). Jakarta: Program Pascasarjana Universitas Negeri Jakarta.

Nugroho, Djoko Hari. 2010. Studi tentang Implementasi Metode Pembelajaran Aktif Berbasiskan Konstruktivisme untuk Prodi Elektronika-Instrumen-STTN.

Seminar Nasional SDM Teknologi Nuklir Yogyakarta, 1978(0176): 111-120

Pranata, I Ketut, dan Suandi, I Ketut. 2010. Implementasi Cooperative Learning dalam Pembelajaran Sistem Akuntansi untuk Meningkatkan Hasil Belajar Mahasiswa Ditinjau dari Prior Knowledge Mahasiswa. Ragam Jurnal Pengembangan Humaniora, 10(2):98-105.

Rahayu, E. dkk. 2011. Pembelajaran Sains dengan pendekatan Keterampilan Proses untuk meningkatkan Hasil Belajar dan Kemampuan Berpikir Kreatif Siswa. Jurnal Pendidikan Fisika Indonesia. 7 (2011):106-110.

Rambuda, A. M., \& Fraser, W. J. 2004. Perceptions of Teachers of the Application of Science Process Skills in the Teaching of Geography in Secondary Schools in the Free State Province. South African Journal of Education, 24(1):10-17.

Rezba R.J, Sprague C.R, McDonnough J.T, \& Matkins J.J. 2006. Learning and Assessing Science Process Skills. USA: Kenda1/Hunt Publishing Company.

Rustaman, Nuryani. 2005. Strategi Pembelajaran Biologi. Malang: UM Press.
Sakdiyah. 2009. Pengaruh Penerapan Pendekatan Kontekstual Terhadap Hasil Belajar Siswa Kelas II IPS Dalam Mata Pelajaran Ekonomi Di SMA Negeri 8 Banda Aceh. Jurnal Serambi Ilmu,7(1):34-40.

Salman, Medinat F. 2009. Active Learning Techniques (ALT) in a Mathematics Workshop; Nigeria Primary School Teacher's Assesment. International Electronic Journal of Mathematics Education, 4(1):23-35.

Suandi, I Ketut. 2006. Evaluasi Keeferktifan Model Pembelajaran Konstruktivis dalam Pencapaian Hasil Belajar Pengantar Akuntansi pada Bidang Tata Niaga Politeknik Negeri Bali. Jurnal Pendidikan dan Pengajaran UNDIKSHA Edisi Khusus XXXIX, 0215 (8250): 1079-1094.

Sudibyo, Elok, Anisjak, Inna Nur, dan Iksa, M. 2008. Pembelajaran Kontekstual untuk Meningkatkan Motivasi dan Hasil Belajar Fisika Siswa SMPN 3 Porong. Jurnal Pendidikan Dasar, 9(1):7-15.

Susiwi, dkk. 2009. Analisis Keterampilan Proses Sains Siswa SMA pada "Model Pembelajaran Praktikum $D-E-H$ ”. Jurnal Pendidikan MIPA, 14(2):87-104.

Tias, W., Tapilouw, F.S. \& Widodo, A. 2008. Perbandingan Pembelajaran Berbasis Inkuiri Melalui Metode Eksperimen dan Demonstrasi pada Topik alat Indera Di SMA. Jurnal Penelitian Pendidikan IPA, 2(3), 339-358.

Temiz B. K, Tasar M. F, Tan M. 2006. Development and Validation of Multiple Format Test of Science Process Skills. International Education Journal, 7(7), 10071027.

Wartono, dan Asim. 2010. Panduan Penyusunan Perangkat Pembelajaran Fisika. Malang. 
Program Studi Pendidikan Fisika FMIPA UM.

Yuniawatika. 2011. Penerapan Pembelajaran Matematika dengan Strategi REACT untuk Meningkatkan Kemampuan Koneksi dan Representasi Matematika Siswa Sekolah Dasar. Edisi Khusus, (2):107-12.

Yunus, H.M. and Hashim, N.H. 2007. Science Process Skills Through English Language Skills Among Year One Pupils, (Online), (http://www.recsam.edu.mycosmed _FullPapers2007_SCIENCE_CS00 9F.pdf diakses 03-04-11). 